\title{
9. STEPWISE CONSOLIDATION OF GLACIGENIC SEDIMENTS RELATED TO THE GLACIAL HISTORY OF PRYDZ BAY, EAST ANTARCTICA ${ }^{1}$
}

\author{
Anders Solheim, ${ }^{2}$ Carl Fredrik Forsberg, ${ }^{3}$ and Alan Pittenger ${ }^{4}$
}

\begin{abstract}
A series of samples from the five sites drilled across the continental shelf and upper slope in Prydz Bay during ODP Leg 119 were consolidation tested in an oedometer. Preconsolidation stresses increase downcore at Sites 739 and 742 in a stepwise manner, and the steps are interpreted to represent periods of increased action of grounded glaciers covering the entire shelf. By the use of theoretical ice sheet surface profiles giving the range of possible ice thicknesses, sediment loading and subsequent erosion seem to be the most important factor for increasing the overconsolidation ratios, and a total glacial erosion exceeding $1 \mathrm{~km}$ is possible. Four separate steps in consolidation, here termed "load events" have been identified. The lowermost load event, 1 , is correlated to the onset of glaciations reaching the shelf edge and an early period of extensive glaciations, starting in early Oligocene or possibly earlier. Glacial activity related to the buildup of ice in West Antarctica in the late Miocene is tentatively correlated to load event 2. Event 3 is the trace of relatively extensive glacial erosion probably in the Pliocene, whereas the upper step in preconsolidation stress, load event 4 , results from the last glaciation reaching the shelf edge, possibly during the late Weichselian. Correlations to other data related to Antarctic glacial history are, however, hampered by the poor age control of the cored diamictites. Consolidation tests may provide a tool for finding the position for hiatuses and unconformities formed subglacially and obscured by subglacial reworking.
\end{abstract}

\section{INTRODUCTION}

The establishment of a glacial history for Antarctica suffers from the general scarcity of deep stratigraphic data from boreholes. Prior to Ocean Drilling Program (ODP) Leg 119, seven sites had been drilled on the Antarctic continental shelf, and all these were in the Ross Sea region (Hayes, Frakes, et al., 1975; Barrett and Treves, 1981; Barrett, 1986, 1989). ODP Leg 113 drilled nine sites in the Weddell Sea region, including three sites on the continental slope off Dronning Maud Land (Leg 113 Shipboard Scientific Party, 1987). Although the results from these sites, and the CIROS-1 site in the Ross Sea (Barrett, 1989), show that the glacial influence on East Antarctica extended back to early Oligocene time, they indicated only limited glaciations in the early Oligocene. Both CIROS-1 and ODP Leg 113 in the Weddell Sea failed to recover the transition from preglacial to glacial sediments.

During ODP Leg 119, four sites were drilled across the shelf (Sites 739 through 742) and one on the upper slope (Site 743) in Prydz Bay (Fig. 1). Although age control is generally sparse, the drilled sequence indicates a fully developed East Antarctic ice sheet by the earliest Oligocene, possibly as early as middle-late Eocene. Barron et al. (this volume) and Hambrey et al. (this volume) give more detailed reviews of the discussions of the glacial history of Antarctica and of the stratigraphic interpretations of the drilled sequence in Prydz Bay.

Geotechnical studies of drilled sediments have been reported only from Deep Sea Drilling Project (DSDP) and ODP sites, and these studies were essentially based on shipboard measurements. The main focus of the present paper is to address the consolidation history of the Prydz Bay shelf sediments through

\footnotetext{
${ }^{1}$ Barron, J., Larsen, B., et al., 1991. Proc. ODP, Sci. Results, 119: College Station, TX (Ocean Drilling Program).

2 Norwegian Polar Research Institute, P.O. Box 158, N-1330, Oslo, Norway.

${ }^{3}$ Norwegian Geotechnical Institute, P.O. Box 40, Tsen, N-0801, Oslo 8, Norway.

${ }^{4}$ Department of Oceanography, Texas A\&M University, College Station, TX 77843, U.S.A.
}

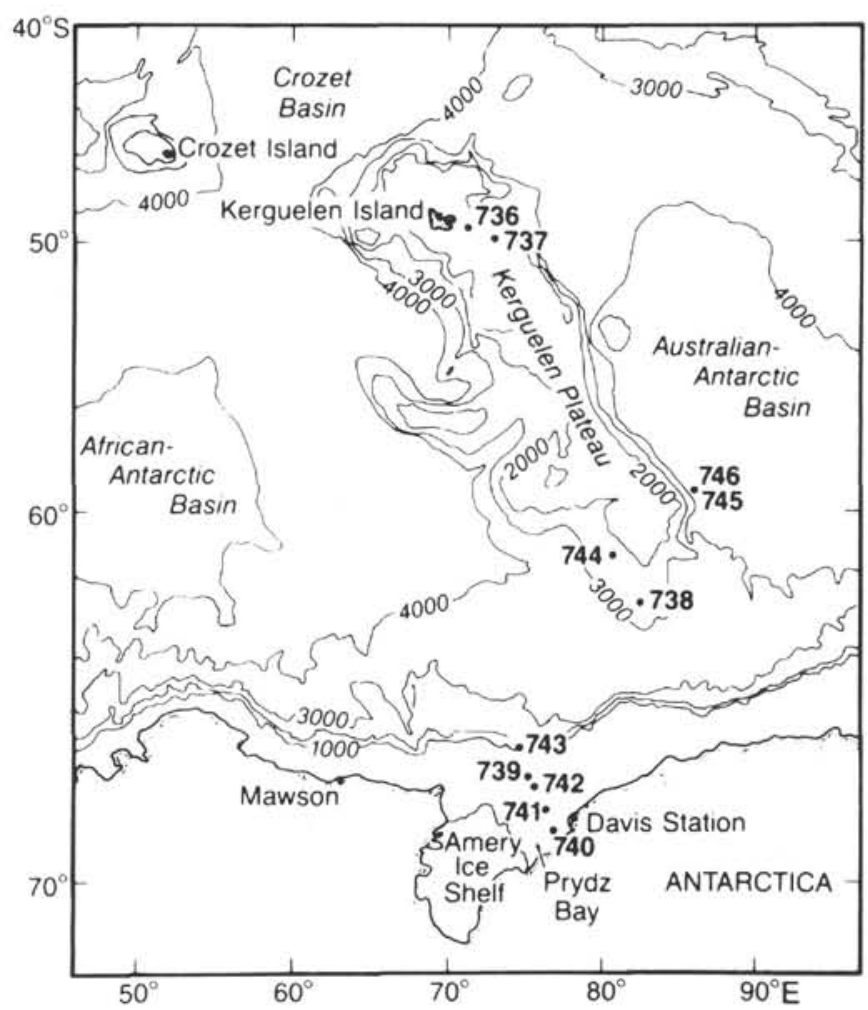

Figure 1. Map showing sites drilled during ODP Leg 119. From Barron, Larsen, et al. (1989).

shore-based consolidation tests. Despite uncertainties, determination of the preconsolidation stress $\left(\mathrm{Pc}^{\prime}\right)$ and its variations provides information of past loads experienced by the tested sample, whether the load was caused by ice or by sediment. Because erosion in a glaciated shelf environment is most likely connected to the action of grounded ice, past loads exceeding 
the present overburden hold important information about glacial oscillations. We discuss the results of consolidation tests from all the Prydz Bay sites, but our main emphasis is placed on the glacigenic sediments of the two outermost sites, 739 and 742. Although most of the sedimentary record is missing in wide hiatuses, we use the present data to place some constraints on the number and extent of major glaciations within the recovered sediments. Furthermore, by the use of theoretical glacier surface profiles, the relative importance of glacier load and erosion for the consolidation characteristics of the sediments is discussed.

\section{MATERIALS AND METHODS}

Shipboard measurements of physical properties provided necessary background information for the shore-based program. The parameters measured during the cruise included water content (percent wet weight), porosity, wet-bulk density, dry-bulk density, grain density, undrained shear strength, compressional$(P$-)wave velocity and thermal conductivity. The methods used and the measurements and results at each site are thoroughly discussed in the Initial Reports part of ODP Leg 119 Proceedings (Barron, Larsen, et al., 1989).

The overall structure of the Prydz Bay continental shelf, as seen seismically (Stagg, 1985; Cooper et al., this volume), consists of a sequence of strata weakly dipping seaward on the inner shelf, followed laterally by more steeply dipping strata on the outer shelf. The latter forms a thick prograding sequence. All dipping strata are cut by a regional angular unconformity and overlain by up to $200 \mathrm{~m}$ of flat-lying strata (Fig. 2).

The drilled sequence consists mainly of clastic sediments, with the exception of a diatomaceous deposit within the uppermost $16.7 \mathrm{~m}$ below seafloor (mbsf) at Site 740 (Barron, Larsen, et al., 1989). The recovered sediments at Site 743 , on the upper continental slope, consist entirely of diamicton. The upper parts of the four shelf sites also consist of diamicton, but this is underlain by stiff diamictites at these sites. At Sites 739 and 742 , various facies of upper Paleogene through Neogene diamictites (with the exception of a few thin diatom-rich siltstone beds) comprise the entire cored sequence below the diamictons. At Sites 740 and 741 , the diamictites are underlain by presumably pre-Tertiary (Truswell, this volume) sand and siltstones. Car- bonate cementation was found in the lower parts of Holes $739 \mathrm{C}$ and $742 \mathrm{~A}$.

The diamictons and diamictites are interpreted to represent various types of glacigenic deposits, ranging from lodgement till through water-laid till to more distal glacial marine deposits. The older, presumably preglacial sediments of Sites 740 and 741 most likely represent continental alluvial plain and fluvial sedimentation (Turner, this volume; Turner and Padley, this volume).

Shore-based geotechnical analyses were made on 24 wholeround core samples (Table 1). Samples are from all the sites and different sediment types, but the main emphasis is on the glacial sediments of Sites 739 and 742 . The three diamicton samples from Sites 740 and 743 (Table 1) were cut from section ends and stored in the plastic liner. All the remaining samples were cut from the core sections after the liner had been removed, but before splitting. This made a brief examination of the core possible before picking the sample, but a full assessment of sample quality for geotechnical work was impossible. Other factors that influenced the selection of whole-round core samples were core recovery and drilling disturbance, in addition to limitations on the number of whole-round samples allowed. In this paper, only the consolidation tests are discussed. The other tests and results are discussed by Solheim et al. (this volume).

The samples were wrapped in plastic and aluminum foil and waxed. They were stored cool aboard ship, air freighted (in a nonfreezing environment), and subsequently stored at $5^{\circ}-8^{\circ} \mathrm{C}$ and about $90 \%$ relative humidity prior to the analyses. Because of the careful treatment and the stiff nature of most of the samples, sample disturbance subsequent to drilling is assumed to be minimal.

All samples were $\mathrm{X}$-rayed prior to opening. The equipment used was a Phillips Model K140 BE, with a voltage of $90-95 \mathrm{kV}$ and 2-min exposure time. The X-radiographs were used to find the best intervals for the different tests, that is, intervals without clasts or fractures.

Eighteen samples were prepared for and tested in oedometer cells, using standard procedures at the Norwegian Geotechnical Institute (NGI) (Sandbækken et al., 1986). The oedometer cells used were $20 \mathrm{~mm}$ high and with cross sections of $20 \mathrm{~cm}^{2}$. The

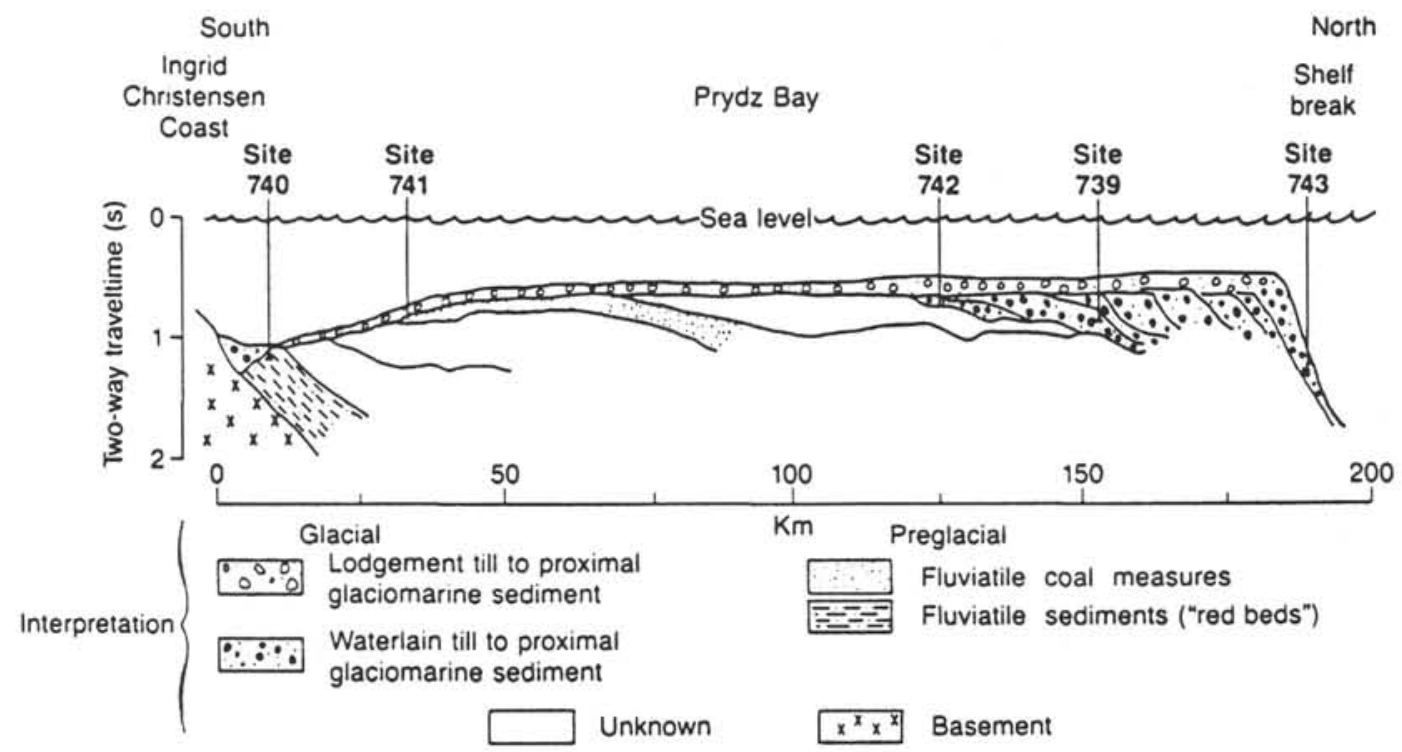

Figure 2. Schematic cross section of the Prydz Bay continental shelf, based on seismic stratigraphy and borehole data from Leg 119 (from Hambrey et al., 1989). 
Table 1. Whole-round core samples from the Prydz Bay Leg 119 sites, with lithology and main geotechnical tests indicated.

\begin{tabular}{|c|c|c|c|c|}
\hline $\begin{array}{l}\text { Sample (core, section, } \\
\text { interval in } \mathrm{cm} \text { ) }\end{array}$ & $\begin{array}{l}\text { Depth } \\
\text { (mbsf) }\end{array}$ & $\begin{array}{l}\text { Length } \\
(\mathrm{cm})\end{array}$ & Lithology & Test \\
\hline \multicolumn{5}{|l|}{$119-739 \mathrm{C}$ - } \\
\hline $4 \mathrm{R}-3,0-15$ & 27.10 & 15 & Massive diamictite & Triax \\
\hline $5 \mathrm{R}-1,94-99$ & 29.64 & 5 & Massive diamictite & Cons \\
\hline $13 \mathrm{R}-1,140-150$ & 107.30 & 10 & Massive diamictite & Cons, DSS \\
\hline $14 \mathrm{R}-2,60-65$ & 117.60 & 5 & Massive diamictite & Cons \\
\hline $15 \mathrm{R}-1,119-124$ & 126.39 & 5 & Massive diamictite & Cons \\
\hline $16 \mathrm{R}-1,135-150$ & 131.65 & 15 & Massive diamictite & Triax \\
\hline $17 \mathrm{R}-2,145-150$ & 137.95 & 5 & Massive diamictite & Cons \\
\hline $19 \mathrm{R}-1,135-150$ & 146.05 & 15 & Massive diamictite & Triax, Perm \\
\hline $21 \mathrm{R}-1,18-23$ & 154.48 & 5 & Massive diamictite & Cons \\
\hline $23 \mathrm{R}-2,31-36$ & 165.81 & 5 & Massive diamictite & UCT \\
\hline $26 \mathrm{R}-2,140-145$ & 186.10 & 5 & Stratified diamictite & Cons \\
\hline $30 \mathrm{R}-5,19-24$ & 227.99 & 5 & Stratified diamictite & Cons \\
\hline \multicolumn{5}{|l|}{$119-740 \mathrm{~A}-$} \\
\hline $3 R-3,145-150$ & 18.15 & 5 & Massive diamicton & Cons \\
\hline \multicolumn{5}{|l|}{$119-741 \mathrm{~A}-$} \\
\hline 5R-2, 91-96 & 35.91 & 5 & Sand/siltstone & Cons \\
\hline $6 \mathrm{R}-1,78-83$ & 43.98 & 5 & Sand/siltstone & Cons \\
\hline $10 \mathrm{R}-2,63-68$ & 84.03 & 5 & Sand/siltstone & Cons \\
\hline \multicolumn{5}{|l|}{$119-742 \mathrm{~A}-$} \\
\hline $8 \mathrm{R}-2,86-91$ & 57.86 & 5 & Massive diamictite & Cons \\
\hline $14 \mathrm{R}-1,21-26$ & 113.51 & 5 & Massive diamictite & Cons \\
\hline $17 \mathrm{R}-1,49-54$ & 142.79 & 5 & Diffusely layered diamictite & Cons \\
\hline $19 \mathrm{R}-5,133-138$ & 169.03 & 5 & Diffusely layered diamictite & UCT \\
\hline $21 \mathrm{R}-2,0-5$ & 182.50 & 5 & Massive diamictite & Cons \\
\hline $23 \mathrm{R}-3,102-107$ & 204.32 & 5 & Massive diamictite & Cons \\
\hline \multicolumn{5}{|l|}{$119-743 \mathrm{~A}-$} \\
\hline $4 \mathrm{H}-3,135-150$ & 8.95 & 15 & Massive diamicton & Triax \\
\hline $9 \mathrm{X}-1,145-150$ & 41.65 & 5 & Massive diamicton & Cons \\
\hline
\end{tabular}

Note: Cons $=$ consolidation test in oedometer; Triax = triaxial test for measurement of undrained shear strength; DSS = direct shear test for measurement of undrained shear strength; UCT = unconfined compression test for measurement of undrained shear strength; Perm = permeability measurement in triaxial cell; All samples are analyzed for grain-size distribution and Atterberg limits.

50-mm-high samples were trimmed down to a diameter slightly greater than the oedometer ring. The cell was coated with silicon grease and the samples were pushed incrementally into the ring while excess material was cut away. Finally, the material exceeding the ring height at the top and bottom was cut away and dry filter stones mounted. The entire mounting procedure was carried out under relative humidity of about $90 \%$ to prevent evaporation from the specimen. Due to the very hard and relatively gravelly character of most of the diamictite samples from Prydz Bay, the trimming procedure was time consuming and great care had to be taken to prevent large pieces of the sample from breaking off.

Two types of loading apparatus were used. The diamicton samples from Sites 740 and 743 were run in a standard NGI oedometer loading apparatus, with a maximum effective axial stress of $5000 \mathrm{kPa}$, while the remaining samples were tested in an apparatus with a maximum effective axial stress of 24,000 $\mathrm{kPa}$. The tests were carried out by constant rate of strain (CRS) loading, with one unload-reload loop taken well beyond the assumed $\mathrm{Pc}^{\prime}$. The test is essentially automatized and load, axial strain, and excess pore pressure are recorded at intervals of 5-10 min and plotted on a semilog scale (Fig. 3 ). In addition to axial strain, the permeability coefficient, $\mathrm{k}$, is computed from the excess pore pressure measured at the bottom of the specimen. Constant-head permeability tests (Lambe and Whitman, 1979) were also carried out for some of the CRS tests, mostly as a check of the computed $\mathrm{k}$ values. Coefficient of consolidation $(\mathrm{Cv})$ is calculated from the $\mathrm{k}$ values and the constrained modulus (M) and recorded. Sandbækken et al. (1986) described in detail the test procedures and computations used.

Three different techniques were used for interpreting the stress-strain curves with respect to $\mathrm{Pc}^{\prime}$. Casagrande's (1936) construction was initially used to find a $\mathrm{Pc}^{\prime}$ that subsequently was checked and sometimes modified by Schmertmann's (1955) method (Fig. 3). The latter method better accounts for possible sample disturbance. In addition, Janbu's (1970) technique using the character of change of the constrained modulus was applied, and the estimated values from this technique are indicated in Table 2. The values further used in this paper are those resulting from the combined Casagrande (1936) and Schmertmann (1955) constructions, as these generally are the most conservative. None of the methods give exact values, and the uncertainties may be considerable. However, use of empirical data from the North Sea, combining undrained shear strength values and Atterberg limits, gives further indications that the $\mathrm{Pc}^{\prime}$ values used here are conservative rather than being too high.

Most drilling disturbance of the diamictites was in the form of fracturing and shearing of the core, and great care was taken to avoid the fractures and shear zones. Possible sample disturbance was also checked against empirical data from offshore Norway (Lacasse, 1988). These data relate sample disturbance to the range of strain likely at loads equal to the present over- 


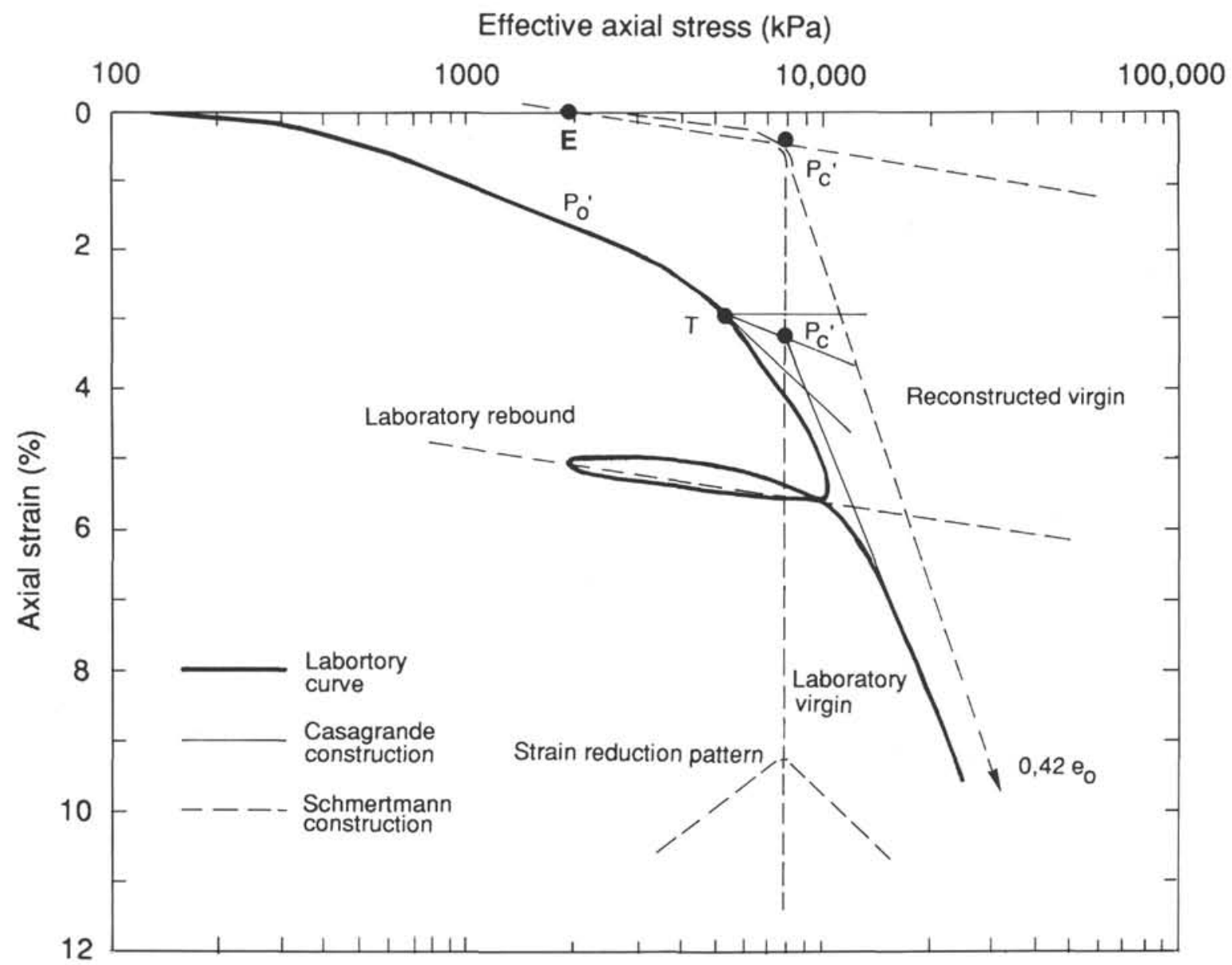

Figure 3. Consolidation test of Sample 119-739C-21R-1, 18-23 cm, showing Casagrande's (1936) and Shmertmann's (1955) methods for estimating the preconsolidation stress $\left(\mathrm{Pc}^{\prime}\right)$. In Casagrande's (1936) construction the point of smallest radius of curvature $(\mathrm{T})$ is determined. The angle formed by the tangent and a horizontal line through $\mathrm{T}$ is bisected and the point of intersection between the bisecting line and the laboratory virgin curve defines the $\mathrm{Pc}^{\prime}$. The $\mathrm{Pc}^{\prime}$ value is tested by Schmertmann's (1955) construction in which point E represents the in-situ conditions. A parallel to the laboratory rebound curve is drawn through $\mathrm{E}$ and a new consolidation curve sketched using this and the straight, reconstructed virgin curve which intersects the laboratory virgin curve at a point equivalent to $0.42 \mathrm{e}_{0}\left(\mathrm{e}_{0}\right.$ is the initial void ratio). Axial strain is subtracted between the two curves and when the strain reduction pattern is symmetrical around $\mathrm{Pc}^{\prime}$, the value is accepted.

burden $\left(\mathrm{P}_{0}{ }^{\prime}\right)$. Based on this and the careful sample treatment, significant disturbance of the stiff diamictites is considered unlikely.

\section{Consolidation Theory}

The basic principles of the Terzaghi consolidation theory, as outlined in standard textbooks on soil mechanics (e.g., Taylor, 1942; Terzaghi, 1943; Atkinson and Bransby, 1978; Lambe and Whitman, 1979), cover the relation between the response of sediment samples to loading and the compaction of the sedimentary column. The most important parameter obtained from oedometer tests in this respect is the coefficient of consolidation $(\mathrm{Cv})$ :

$$
\mathrm{Cv}=\mathrm{k}(\mathrm{M} / \mathrm{G})
$$

where $\mathrm{k}$ is the coefficient of permeability, $\mathrm{M}$ the constrained modulus, and $\mathrm{G}$ the unit weight of water. In general, $\mathrm{Cv}$ is constant or increases only slowly with vertical stress in the virgin compression zone. This reflects the decrease in permeability and the increase in modulus as the sample is consolidated.
Calculation of the consolidation of the sedimentary column is in general first approached by introducing two dimensionless variables:

$$
\mathrm{Z}=\mathrm{z} / \mathrm{H} \text { and } \mathrm{T}=\mathrm{Cv} \mathrm{t} / \mathrm{H}^{2} \text {, }
$$

where $\mathrm{z}$ is the depth in the sediment, $\mathrm{H}$ the total thickness of the sediment column (down to impermeable base), and the time. $T$ is a dimensionless time factor. The behavior of the sediment column is given by the following differential equation:

$$
\partial \mathrm{u}^{2} / \partial \mathrm{Z}^{2}=\partial \mathrm{u} / \partial \mathrm{T}
$$

where $\mathrm{u}$ is the excess pore pressure (above hydrostatic). Initially, the entire load results in a pore pressure increase, so that at $t=$ 0 , the effective stress increase equals zero. As the excess pore pressure at the sediment surface can be assumed to dissipate instantaneously, the boundary condition for all $t$ is $\mathrm{u}=0$ for $\mathrm{Z}=$ 0 . Figure 4 shows solutions for a homogeneous (constant $\mathrm{Cv}$ ) sedimentary column. The consolidation ratio $\mathrm{Uz}$ is defined as 
Table 2. Consolidation test results. $\mathbf{P}_{0}$ ' is calculated from the shipboard measurements of wet-bulk density.

\begin{tabular}{|c|c|c|c|c|c|c|c|}
\hline $\begin{array}{l}\text { Sample (core, section, } \\
\text { interval in } \mathrm{cm} \text { ) }\end{array}$ & $\begin{array}{l}\text { Depth } \\
\text { (mbsf) }\end{array}$ & $\begin{array}{l}\mathrm{P}_{0}^{\prime} \\
(\mathrm{kPa})\end{array}$ & $\begin{array}{l}\mathrm{Pc}^{\prime} \\
(\mathrm{kPa})\end{array}$ & $\begin{array}{l}\mathrm{Pc}^{\prime} \mathrm{J} \\
(\mathrm{kPa})\end{array}$ & OCR & $\begin{array}{c}\mathrm{n} \\
(\%)\end{array}$ & $\begin{array}{c}k \\
(\mathrm{~m} / \mathrm{y})\end{array}$ \\
\hline \multicolumn{8}{|l|}{$119-739 \mathrm{C}$ - } \\
\hline $5 R-1,94-99$ & 29.64 & 335 & 2000 & 2000 & 6.0 & 19 & 0.015 \\
\hline $13 \mathrm{R}-1,140-150$ & 107.30 & 1410 & 2900 & 3000 & 2.1 & 24 & 0.0008 \\
\hline $14 R-2,60-65$ & 117.60 & 1511 & 6200 & 5900 & 4.1 & 19 & 0.0006 \\
\hline $15 \mathrm{R}-1,119-124$ & 126.39 & 1596 & $(6000)$ & $(6200)$ & 3.8 & 21 & 0.0015 \\
\hline $17 R-2,145-150$ & 137.95 & 1748 & 7000 & 6000 & 4.0 & 22 & 0.0003 \\
\hline $2 \mid R-1,18-23$ & 154.48 & 1951 & 8000 & 8000 & 4.1 & 26 & 0.002 \\
\hline $26 \mathrm{R}-2,140-145$ & 186.10 & 2334 & 8200 & 8500 & 3.5 & 45 & 0.005 \\
\hline $30 \mathrm{R}-5,19-24$ & 227.99 & 2829 & 10000 & 12000 & 3.5 & 39 & 0.0015 \\
\hline \multicolumn{8}{|l|}{$119-740 \mathrm{~A}$ - } \\
\hline $3 R-3,145-150$ & 18.15 & 80 & 100 & 100 & 1.3 & 38 & 0.036 \\
\hline \multicolumn{8}{|l|}{$119-741 \mathrm{~A}-$} \\
\hline $5 R-2,91-96$ & 35.91 & 420 & $>10000$ & $>10000$ & $>24$ & 29 & $0.02(?)$ \\
\hline $6 \mathrm{R}-1,78-83$ & 43.98 & 483 & $>10000$ & $>10000$ & $>21$ & 27 & 0.00007 \\
\hline $10 \mathrm{R}-2,63-68$ & 84.03 & 964 & $>10000$ & $>10000$ & $>10$ & 30 & 0.0002 \\
\hline \multicolumn{8}{|l|}{ 119-742A- } \\
\hline $8 R-2,86-91$ & 57.86 & 705 & 2000 & 1000 & 2.8 & 24 & 0.003 \\
\hline $14 \mathrm{R}-1,21-26$ & 113.51 & 1390 & 2000 & 3500 & 1.4 & 25 & 0.007 \\
\hline $17 \mathrm{R}-1,49-54$ & 142.79 & 1639 & $(6000)$ & (5500) & 3.7 & 22 & 0.002 \\
\hline $21 \mathrm{R}-2,0-5$ & 182.50 & 2115 & 7500 & 5000 & 3.5 & 28 & 0.0003 \\
\hline $23 R-3,102-107$ & 204.32 & 2446 & 9000 & 10500 & 3.7 & 25 & 0.0012 \\
\hline \multicolumn{8}{|l|}{$119-743 \mathrm{~A}-$} \\
\hline $9 X-1,145-150$ & 41.65 & 502 & 400 & 400 & 0.8 & 28 & 0.002 \\
\hline
\end{tabular}

Note: $\mathrm{P}_{0}{ }^{\prime}=$ In-situ effective stress; $\mathrm{Pc}^{\prime}=$ preconsolidation stress estimated by the combined Casagrande's (1936) and Schmertmann's (1955) techniques; $\mathrm{Pc}^{\prime} \mathrm{J}=$ preconsolidation stress estimated by Janbu's (1970) technique; OCR = overconsolidation ratio $\left(\mathrm{P}_{0}{ }^{\prime} / \mathrm{Pc}^{\prime}\right) ; \mathrm{n}=$ porosity at $\mathrm{P}_{0}$, calculated from void ratio measured during test; $\mathrm{k}=$ permeability at $\mathrm{P}_{0}^{\prime}$.

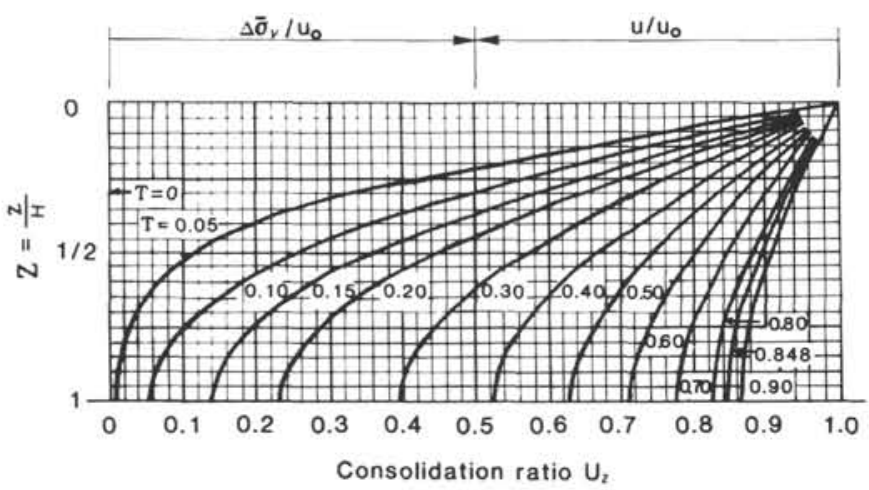

Figure 4. Consolidation ratio as a function of depth and time factor for uniform initial excess pore pressure (modified from Lambe and Whitman, 1979).

$1-\mathrm{u} / \mathrm{u}_{0}$, where $\mathrm{u}_{0}=\mathrm{u}$ for $\mathrm{t}=0$. Although consolidation will never be mathematically complete, it is convenient to assume a complete compaction (i.e., complete dissipation of pore pressure) when $T=1$. The time for complete consolidation of the sedimentary column is therefore given by

$$
\mathrm{t}=\mathrm{H}^{2} / \mathrm{Cv} \text {. }
$$

The consolidation time is independent of the load (Terzaghi, 1943), and for values of T less than 0.05 , the base of the sedimentary column is not influenced by consolidation. The top of the sediment is, however, fully consolidated.
Table 3 shows the times needed to compact the sedimentary sections between horizons indicative of load events in the present study. The base of each section is taken as the previous load, as no significant consolidation of an already compacted sediment can be achieved. The almost impermeable nature of the sediments (Table 2) precludes downward drainage. It should be noted that Table 3 represents an ideal situation. Deviations from this in a real situation would most likely increase the consolidation time. This may be caused by longer (relative to vertical) routes for excess porewater dissipation as well as vertical and lateral permeability differences. The latter may cause damming effects for pore water under different zones of the glacier (Boulton and Paul, 1976).

On the other hand, if both upward and downward drainage should occur, the consolidation time would decrease exponentially in accordance with the preceding equation. Ollier and Mathis (this volume) found sandy and gravelly layers in nonrecovered intervals from downhole logs at Sites 739 and 742 . These could provide possible drainage routes. In any case, the calculations (Table 3) are only meant as an indication that consolidation will be achieved within time spans in the order of $5000 \mathrm{yr}$.

A temporary load may not have time to completely compact the sediment column. Beneath a glacier, high hydrostatic pressures may prevent loading of the sediments (Boulton and Paul, 1976), but ephemeral reductions in this pressure will cause episodes of loading that may be recorded in the sediments. The preconsolidation stresses measured just below such load events may therefore represent minimum values for past glacial loads.

Erosion, on the other hand, may cause a significant increase in overconsolidation ratio (OCR) through removal of overburden (i.e., decreasing $P_{0}{ }^{\prime}$ ). The eroded sediment may represent 
Table 3. Calculated consolidation times for the sedimentary sections between interpreted load events.

\begin{tabular}{lrcccr}
\hline Site & $\begin{array}{c}\text { Depth } \\
\text { interval } \\
(\mathrm{mbsf})\end{array}$ & $\begin{array}{c}\text { Thickness } \\
(\mathrm{m})\end{array}$ & $\begin{array}{c}\text { Coefficient of } \\
\text { consolidation } \\
\left(\mathrm{m}^{2} / \mathrm{yr}\right)\end{array}$ & $\begin{array}{c}\text { Time } \\
\text { factor } \\
(\mathrm{T})\end{array}$ & Time \\
\hline 739 & $24.0-113.0$ & 89.0 & 12 & 1 & 660 \\
739 & $113.0-146.0$ & 33.0 & 7 & 1 & 156 \\
739 & $146.0-192.0$ & 46.0 & 4 & 1 & 529 \\
739 & $192.0-310.0$ & 118.0 & 4 & 1 & 3481 \\
739 & $24.0-113.0$ & 89.0 & 12 & 0.05 & 33 \\
739 & $113.0-146.0$ & 33.0 & 7 & 0.05 & 8 \\
739 & $146.0-192.0$ & 46.0 & 4 & 0.05 & 26 \\
739 & $192.0-310.0$ & 118.0 & 4 & 0.05 & 174 \\
742 & $6.0-134.0$ & 128.0 & 15 & 1 & 1092 \\
742 & $134.0-195.0$ & 61.0 & 5 & 1 & 744 \\
742 & $195.0-304.0$ & 109.0 & 5 & 1 & 2376 \\
742 & $6.0-134.0$ & 128.0 & 15 & 0.05 & 55 \\
742 & $134.0-195.0$ & 61.0 & 5 & 0.05 & 37 \\
742 & $195.0-304.0$ & 109.0 & 5 & 0.05 & 119 \\
\hline
\end{tabular}

Note: For $\mathrm{T}=0.05$ (and less), only the top of the sediment, immediately beneath the applied load, is consolidated, whereas for $\mathrm{T}=$ 1 , the sedimentary section is fully consolidated throughout.

long time intervals (e.g., the early Oligocene-late Miocene hiatus in Prydz Bay, Site 739) during which the sediment probably achieved full consolidation throughout (Table 3). $\mathrm{OCR}=\mathrm{Pc}^{\prime} /$ $\mathrm{P}_{0}^{\prime}$.

\section{CONSOLIDATION TEST RESULTS}

With the exception of Samples 119-740A-3R-3, 145-150 cm, 119-743A-9X-1, 145-150 cm, and 119-742A-14R-1, 21-26 cm, all tested samples are overconsolidated (Table 2). Most of the consolidation curves have a relatively flat appearance with no distinct break in slope (point of smallest radius of curvature), which makes them relatively difficult to interpret with respect to $\mathrm{Pc}^{\prime}$. However, by the use of the three different interpretation techniques, the majority of the calculated values are considered reliable. The consolidation curves are shown in Figure 5 as axial strain vs. stress. A composite plot of void ratio vs. stress (Fig. 6) gives a better comparison of curves, because the initial void ratio differs considerably between individual samples, mainly reflecting their different lithologic character (Solheim et al., this volume). All tested samples, however, have a clay fraction exceeding $30 \%$, and therefore are geotechnically classified as clays (Janbu, 1970).

\section{Site 739}

Eight samples from this site were consolidation tested (Fig. 5A). Due to technical problems, Samples 119-739C-14R-2, 60$65 \mathrm{~cm}$, and 119-739C-15R-1, 119-124 cm, were not run with unload-reload loops. Furthermore, the results for the latter sample may be questionable also because the top filter stone of the oedometer (Sandbækken et al., 1986) was found to be slightly tilted, possibly due to coarse material. All the tests are carried out on stiff diamictites most likely of Oligocene through Pliocene age (Leg 119 Shipboard Scientific Party, 1988). Only the two deepest Samples 119-739C-26R-2, 140-145 cm, and 119739C-30R-5, 19-24 cm, are from a sequence of stratified sediments, whereas the six shallower samples are from massive, homogeneous diamictites. Tests of the five shallowest samples show relatively flat curves with deformation generally less than $10 \%$. The three deepest sample tests are considered the best with respect to calculation of $\mathrm{Pc}^{\prime}$. They show clear points of smallest radius of curvature and the virgin compression curves are easy to determine, in particular for the two samples from Cores 119-
739C-26R and 119-739C-30R (Figs. 5A and 6). The differences between the curves can most likely be ascribed to different grainsize distributions (Solheim et al., this volume). The higher proportions of fines in the two latter samples are also reflected in their higher initial void ratios (Fig. 6).

\section{Site 740}

Only one sample was tested from this site, 119-740A-3R-3, $145-150 \mathrm{~cm}$ (Figs. 5B and 6), from the upper section of diamicton of presumably Quaternary age. The sample shows normal consolidation (Table 2), which also was inferred from the shipboard measurements (Barron, Larsen, et al., 1989).

\section{Site 741}

Three samples were tested (Figs. 5C and 6), all from lithostratigraphic Unit IV (Barron, Larsen, et al., 1989) and consisting of fine-grained, presumably alluvial siliciclastic rocks, possibly as old as early Cretaceous (B. Tocher, pers. comm., 1989; Truswell, this volume). The consolidation curves for the three samples have relatively similar shapes, with deformations of only $3 \%-5 \%$ with $24,000 \mathrm{kPa}$ effective axial stress (Fig. 5C). The curves are difficult to interpret with respect to $\mathrm{Pc}^{\prime}$, and a component of cementation cannot be ruled out. However, no cementation was observed during shipboard work (Barron, Larsen, et al., 1989), and the $\mathrm{Pc}^{\prime}$ values seem to range between 10,000 and $20,000 \mathrm{kPa}$.

\section{Site 742}

Five samples of massive to diffusely layered diamictite (Table 1), possibly of Oligocene through Pliocene age, were tested (Fig. 5D). One test, of Sample 119-742A-17R-1, 49-54 cm, was stopped before the unload-reload loop (Fig. 5D), and the interpretation of this curve is therefore uncertain as true virgin compression may not have been reached. The real value of Pc' may hence be higher (Table 2). The consolidation curves for Site 742 generally overlap well with the curves from Site 739 (Fig. 6). A slightly higher average initial void ratio relative to the bulk of the tests from Site 739 reflects a slightly higher average clay content in the tested samples from Site 742 (Solheim et al., this volume).

\section{Site 743}

Relatively soft diamicton was recovered throughout Hole 743A. Only one consolidation test was carried out, at $40.2 \mathrm{mbsf}$ (Figs. 5B and 6). The result may indicate a weak underconsolidation (Table 2), but due to poor core recovery in the upper 40 mbsf, uncertainties in the determination of the in-situ pressure $\left(\mathrm{P}_{0}{ }^{\prime}\right)$ may be the reason for this. Furthermore, the consolidation curve (Fig. 5B) indicates that the relatively soft sample may be somewhat disturbed. With only one test, and the mentioned uncertainties, a normal consolidation is considered likely.

\section{DISCUSSION}

\section{Causes for the Overconsolidation}

Overconsolidation of a sediment can be caused by past overburden, diagenesis, drying, freezing, or by secondary compression (creep). Shipboard sedimentological studies indicated no cementing in the geotechnically tested intervals of the diamictites (Barron, Larsen, et al., 1989). The noncemented nature of the tested diamictites is further supported by land-based geochemical studies (S. Chambers, pers. comm., 1990; R. Cranston, pers. comm., 1990). Samples between 166 and 318 mbsf at Site 739 generally contain diatoms. Diatom frustules may have a bonding effect on the sediment, but this is unlikely to withstand the stresses involved in the consolidation tests of the present study. Present-day water depths are more than $400 \mathrm{~m}$, and past eustatic fluctuations have not significantly exceeded $100 \mathrm{~m}$, with 
A

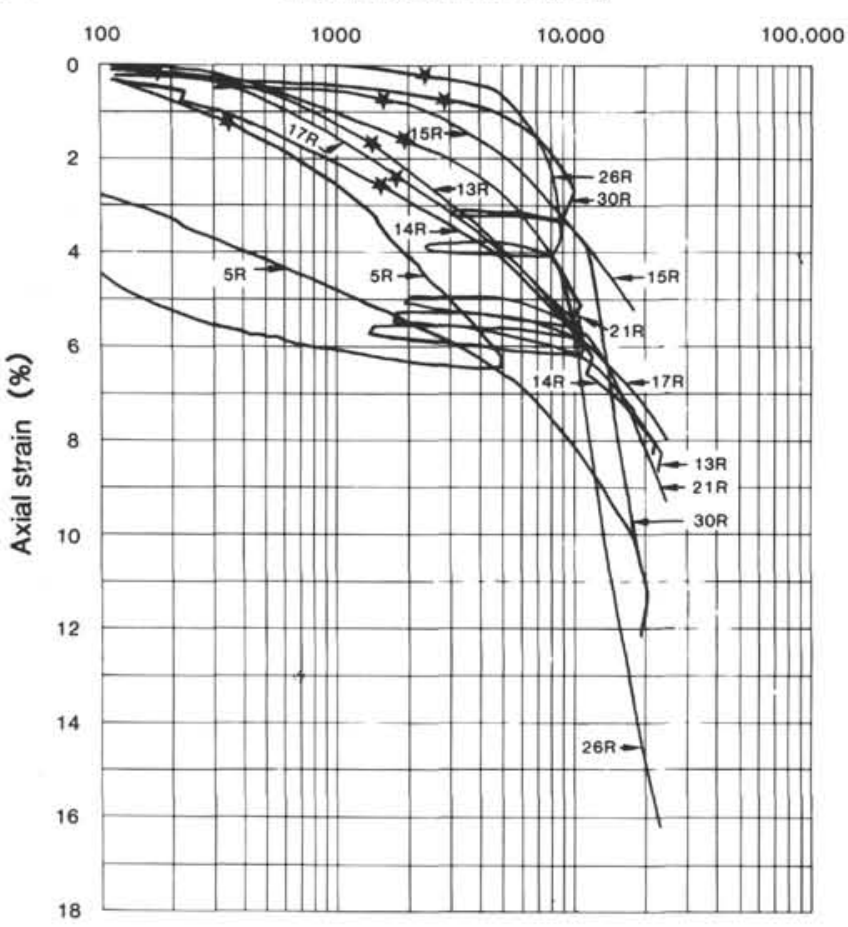

C

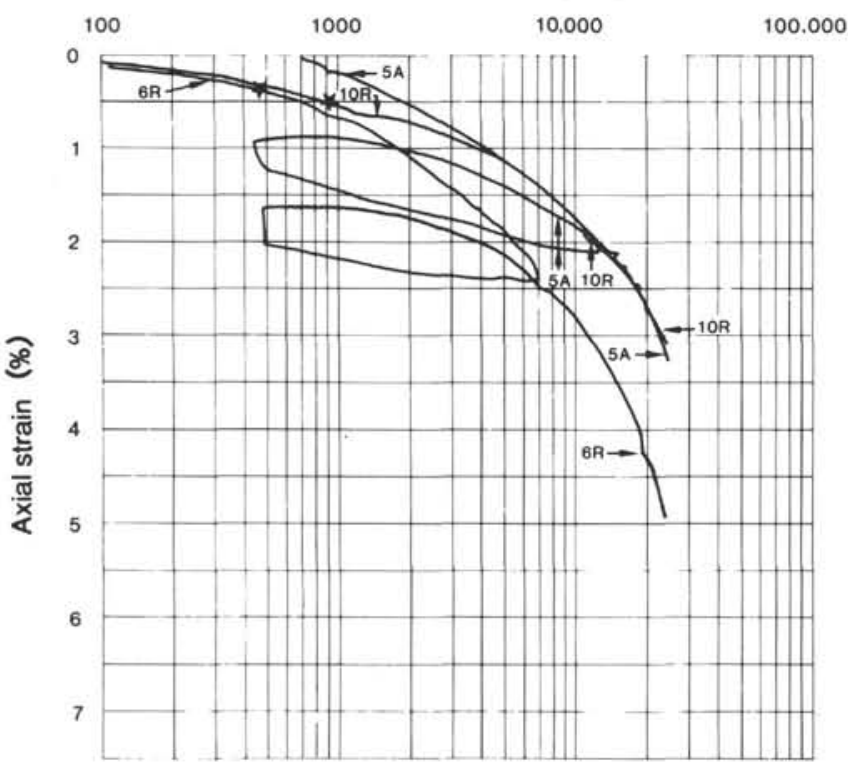

B Effective axial stress $(\mathrm{kPa})$

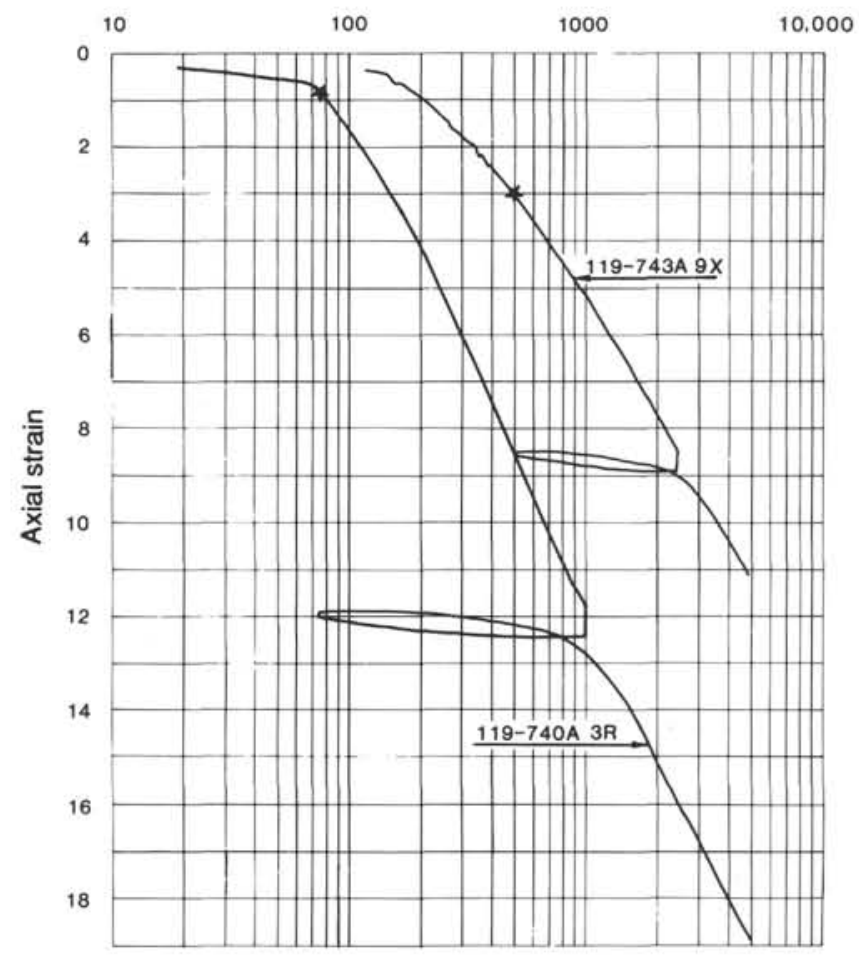

D Effective axial stress $(\mathrm{kPa})$

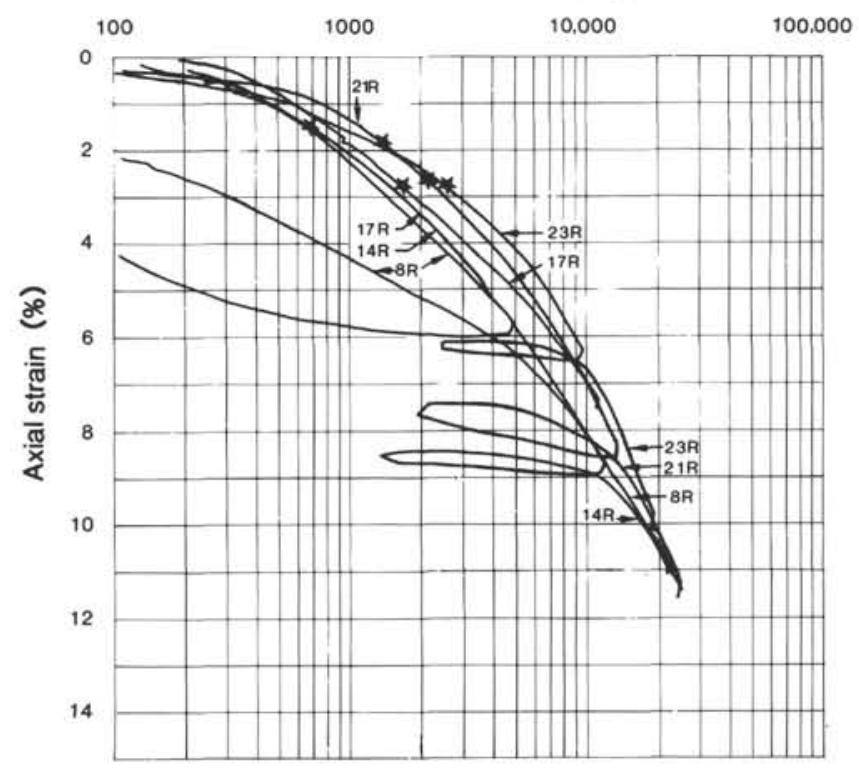

Figure 5. Consolidation test results from Leg 119 sites. $\mathrm{P}_{0}{ }^{\prime}$ is marked with an asterisk at each curve. Core numbers are indicated. For more detailed sample identification, see Table 1. A. Site 739. B. Sites 740 and 743. C. Site 741. D. Site 742.

an eustatic sea level generally deeper than at present during most of the Tertiary (Haq et al., 1987). We therefore consider drying to be an unlikely cause of overconsolidation, although no specific information exists on relative water depth. A frozen sediment would have a greatly increased strength in itself, but freezing may also cause overconsolidation through suction in front of the freezing front (Boulton and Paul, 1976). Furthermore, repetitive freezing and thawing may cause overconsolida- tion through rearrangement of particles (Chamberlain and Gow, 1978; Chamberlain, 1979, 1989). However, no frozen sediments were cored, and past frozen conditions would, most likely, have left an imprint in the form of traces after segregation lenses, jointing, and shrinkage cracks (Boulton and Paul, 1976; Chamberlain and Gow, 1978).

This leaves past overburden as the most probable cause of overconsolidation. As this is a glacial environment, and major 


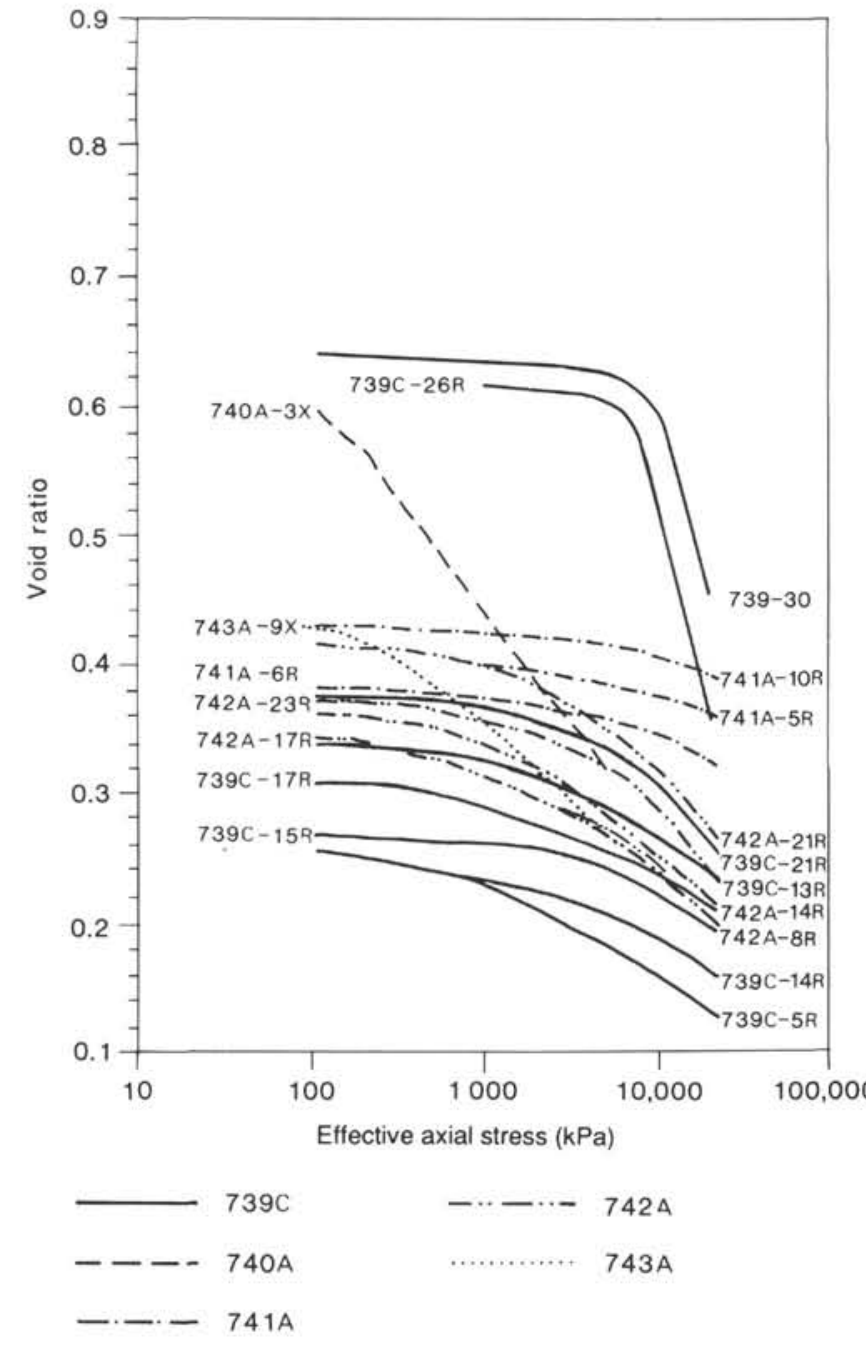

Figure 6. Composite plot of all the consolidation tests, with axial stress plotted against void ratio. The unload-reload loops are omitted for clarity.

parts of the diamictites have been interpreted as deposited in a glacier proximal environment or as lodgement tills (Hambrey et al., 1989), a relation to grounded glacier ice during periods of an expanded East Antarctic ice sheet is likely. A grounded ice sheet will exert a load on the substratum by its own weight, but additionally, both the advance of a grounded ice sheet and the glacier activity during the glaciation may cause significant erosion, decreasing the overburden and therefore raising the overconsolidation ratio (OCR), which is defined as $\mathrm{Pc}^{\prime} / \mathrm{P}_{0}{ }^{\prime}$.

Secondary compression without stress increase (creep) introduces a complicating factor. The relative importance of secondary and primary compression as well as the creep rate, vary with sediment type. The effect of creep is highest for normally consolidated, highly plastic, organic rich sediments, and almost negligible for overconsolidated sediments (Lambe and Whitman, 1979). Rates are often expressed by the slope of the creep curve,

$$
\mathrm{c}_{\delta}=(\Delta \mathrm{H} / \mathrm{H}) / \Delta \log _{10} \mathrm{t}
$$

with $\mathrm{c}_{\delta}$ defined per logarithmic decade in a semi-log scale. However, most creep experiments pertain to the settlements of manmade structures and therefore may not be valuable in a geologic time frame. $c_{\delta}$ may only be constant for the first few time decades and then decrease, as indicated by 1 -yr experiments in Nor- way (T. Berre, pers. comm., 1990). Creep has, however, probably had a consolidating effect on the sediments of the present study, given the long time intervals involved.

\section{Prydz Bay Load Events}

Despite uncertainties in the use of preconsolidation stress, the fact remains that the cored diamictites are overconsolidated. Furthermore, $\mathrm{Pc}^{\prime}$ shows downhole steps that are too great to be explained by the increase in present overburden. From the preceding discussion, we ascribe the former to past overburden of ice and/or sediment and the latter to distinct periods of excess loading on a regional scale, here termed load events (i.e., periods of increased glaciation). Note that the term "event" here means a step in $\mathrm{P}_{\mathrm{c}}{ }^{\prime}$ (and OCR) between individual laboratory tests, and does not necessarily imply short time. Rather, the individual events may represent relatively long time intervals, as the resolution is hampered by the sparse number of tests. A correlation of load events across the shelf (Fig. 7) gives a broad picture of the large-scale glacial variations of the region. A maximum of four load events were identified and numbered 1 through 4 , starting with the deepest. Great uncertainties in the correlations are caused by the large regional hiatuses (Larsen and Barron, this volume). The error bars on the $\mathrm{P}_{\mathrm{c}}{ }^{\prime}$ values (Fig. 7) indicate only estimated uncertainties in the Casagrande (1936) and Schmertmann (1955) constructions of $\mathrm{P}_{\mathrm{c}}{ }^{\prime}$. Values estimated from Janbu's (1979) method (Table 3) generally define the individual events more clearly. Lithologic changes, unconformities, and changes in other physical properties are also taken into account in placing the events.

Despite a mixed fossil content, also including pre-Quaternary fossils, Site 743 is probably of Quaternary age throughout (Hambrey et al., 1989) and is also presently beyond the water depth that can be reached by grounded glaciers. The remaining four sites all show a step from normal consolidation to overconsolidation within the upper $20 \mathrm{mbsf}$. Although the position of this boundary is not determined in detail because of poor core recovery and the sparse number of consolidation tests (Fig. 7), it can usually be placed within a $5 \mathrm{~m}$ accuracy based on changes in other physical properties and lithostratigraphy. This is the only geotechnical boundary that can be correlated through all four shelf sites, and we find a relation to the last glaciation that covered the entire shelf with grounded ice reasonable.

Due to the poor core recovery, no geotechnical information can be extracted from the diamictites of Sites 740 and 741 . The next major step in Pc' $^{\prime}$ of these two most landward sites is at the boundary between the diamictites and the terrestrial sedimentary rocks, which are of preglacial age (Hambrey et al., 1989). The high $\mathrm{Pc}^{\prime}$ values of these sediments, measured at Site 741, indicate a significant past load (or are also affected by cementation), but give no further information on individual events $(\mathrm{Ta}-$ ble 2 and Fig. 7).

At Sites 739 and 742 , three and two steps, respectively, are seen in the $\mathrm{Pc}^{\prime}$ values below the upper, Quaternary event (Fig. 7). Due to the relatively sparse number of tests, the vertical resolution is poor, and all available information was used to locate the actual events.

At Site 739, event 1 is identified by an increase in $\mathrm{Pc}^{\prime}$ of $2000 \mathrm{kPa}$ between tests at 186.1 and $228.0 \mathrm{mbsf}$ (Fig. 7). Based on the interpretation of lithostratigraphic Subunit IIIB as a distal glacial marine sediment (Barron, Larsen, et al., 1989), the load event is placed at the boundary between lithostratigraphic Subunits IIIB and IIIA. Subunit IIIB then represents an erosional remnant from a period when the ice sheet margin was located farther landward (i.e., an interstadial).

The next load event (2) at Site 739 is placed at $140 \mathrm{mbsf}$, between $\mathrm{Pc}^{\prime}$ values of approximately 7000 and $8000 \mathrm{kPa}$ at 137.95 and 154.48 mbsf, respectively (Fig. 7). A small but distinct peak 


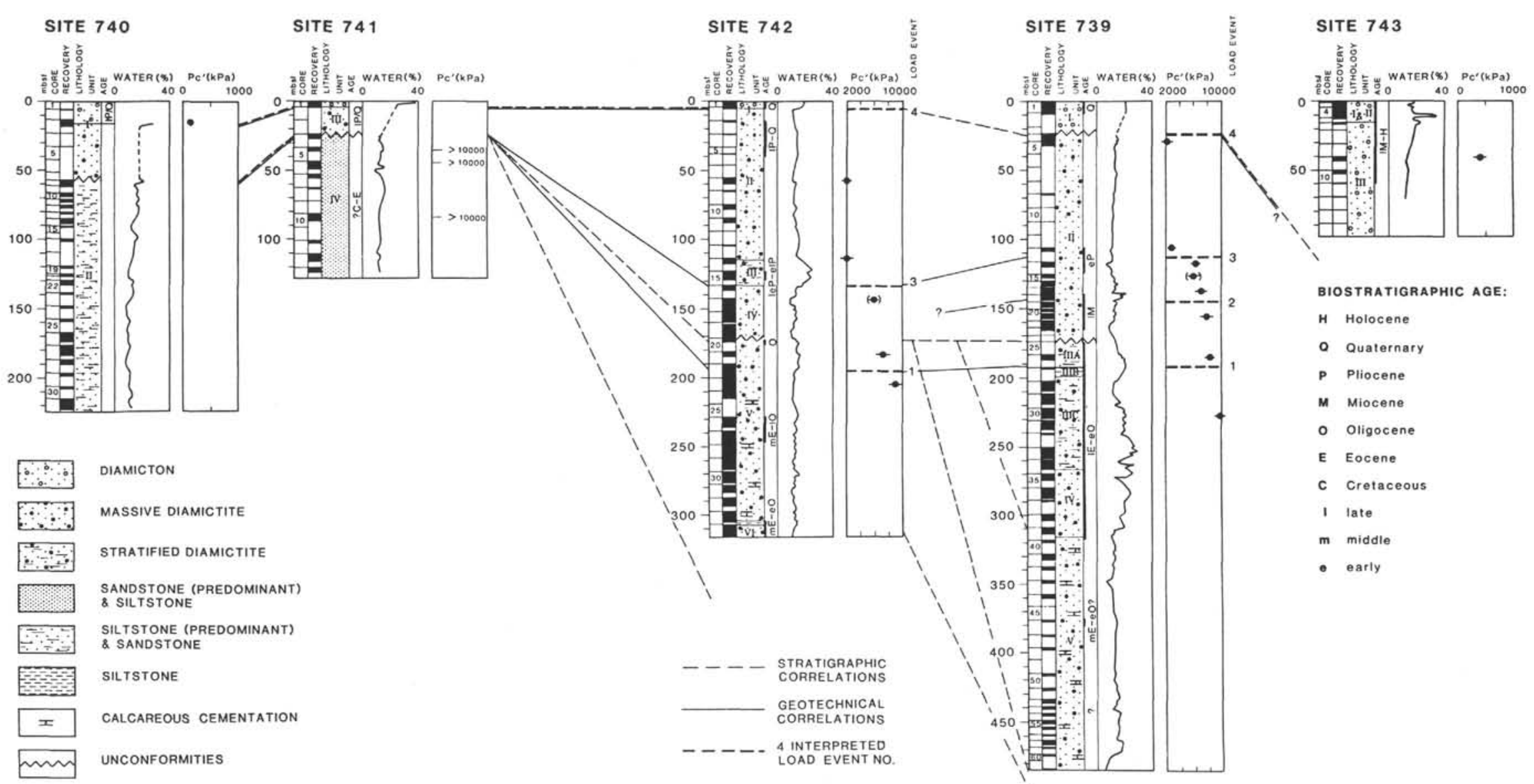

Figure 7. Stratigraphic and geotechnical logs for the Prydz Bay sites, both lithostratigraphic and geotechnically correlated across the shelf. Water content in percent of wet weight is from the shipboard measurements (Barron, Larsen, et al., 1989). Bracketed Pc' symbols for Sites 739 and 742 mark uncertain values due to technical reasons, as further discussed in the text. The lithology is from Hambrey et al. (1989). Ages are from shipboard-determined biostratigraphy (Barron, Larsen, et al., 1989). See text for discussion on the position of load events. 
in the water content indicates a lithologic change in this interval (Fig. 7), an observation which is further supported by an apparently lower clast content, as seen in the photographs of Core 119-739C-18R (Barron, Larsen, et al., 1989). Furthermore, two triaxial tests show an increase in undrained shear strength from $1700 \mathrm{kPa}$ at $132 \mathrm{mbsf}$ to $2500 \mathrm{kPa}$ at $146 \mathrm{mbsf}$ (Solheim et al., this volume). Given this information, event 2 is placed at the top of the thin layer of apparently more fine-grained sediment. As for load event 1 , this could represent the erosional remnants of a more distal sediment representing an interstadial.

Load event 3 is the most distinct of the recorded steps in $\mathrm{Pc}^{\prime}$ at Site 739 , increasing more than $3000 \mathrm{kPa}$ over a 10 -m interval, from 107.3 to $117.6 \mathrm{mbsf}$ (Fig. 7). As this event apparently does not correspond with lithological or other physical-properties changes, it is placed midway between the two consolidation tests. The core recovery is poor in this interval, and changes in lithology and/or other physical properties may remain undetected due to undersampling. However, from sonobuoy records a refractor $(\beta)$ is situated approximately at this depth (Barron, Larsen, et al., 1989), giving further support to the position of the interpreted load event.

At Site 742, only two significant steps in $\mathrm{Pc}^{\prime}$ are determined by consolidation tests. The upper, Quaternary event is inferred from lithostratigraphy and shipboard measurements. Because the $\mathrm{Pc}^{\prime}$ at 142.79 mbsf is considered uncertain (too low), load event 2 is not indicated at this site. The lower step, event 1 , is placed between $\mathrm{Pc}^{\prime}$ values of 7500 and $9000 \mathrm{kPa}$ at 182.5 and 204.3 mbsf, respectively (Fig. 7). From seismic stratigraphy and biostratigraphy, combined with the magnitude of the $\mathrm{Pc}^{\prime}$ values, we find it likely that this event correlates with event 1 at Site 739. The event is placed at 195 mbsf, based on changes in other physical properties (Fig. 7), also interpreted to mark facies changes (Solheim et al., this volume).

From the magnitude of the increase in $\mathrm{Pc}^{\prime}$ between 113.5 and $142.8 \mathrm{mbsf}$, from 2000 to at least $6000 \mathrm{kPa}$, we correlate this event with event 3 of Site 739. This is also supported by the biostratigraphic control, giving a Pliocene age for the event at both sites. The event is placed at the base of lithostratigraphic Unit III, a stratified diamictite containing sediment of a more distal glacial marine character than the underlying Unit IV (Barron, Larsen, et al., 1989). The fact that Sample 119-742A-14R-1, 21-26 cm, at 142.8 mbsf shows nearly normal consolidation (Table 2) implies that loading of a similar magnitude and duration as for events 1 through 3 cannot have taken place after event 3. Further support for this interpretation is found in lithostratigraphic Unit III. Shipboard measurements of undrained shear strength in general show a great scatter and are above or in the upper part of the reliable range of the instruments used (Barron, Larsen, et al., 1989). Undrained shear strength values of around $400 \mathrm{kPa}$ in Unit III are, however, considered reliable. Combining the ratio of undrained shear strength and $\mathrm{P}_{0}{ }^{\prime}$ with the plasticity index (Solheim et al., this volume) and comparing this with empirical data (Brooker and Ireland, 1965; Andresen et al., 1979) give normal consolidation for this unit.

\section{Ice Thickness and Erosion}

Based on the uncertainties related to excess pore pressures, Boulton and Paul (1976) claimed that using $\mathrm{Pc}^{\prime}$ in reconstructing past ice thickness is fallacious. We do not dispute this, but consider the two following points important for the discussion of the Prydz Bay sequence:

1. Stepwise increase of $\mathrm{Pc}^{\prime}$ is evidence of past loading/erosion.

2. $\mathrm{Pc}^{\prime}$ values can be used in broad estimates of minimum values for the past excess overburden.
Given this, ranges of possible past excess overburden in the form of ice or sediment can be estimated (Table 4).

A pure ice load as cause for the preconsolidation (Table 4) gives ice thicknesses above sea level that are too high for load events 1, 2, and 3, for any known or theoretical ice surface profile (Vialov, 1958; Boulton and Jones, 1979; Paterson 1981; Drewry, 1983; Drewry and Robin, 1983). The shelf edge is the outermost limit for grounded ice, and extensive, buttressing ice shelves would most likely not exist beyond the shelf edge, given no anchor point or restricted embayment. Therefore, an ice sheet would become unstable and calve off at, or shortly beyond, the shelf edge. The observed overconsolidation is probably caused by a combined effect of glacier load and erosion. Theoretical glacier profiles would give the range of possible ice thicknesses, and hence the limitations on the amount of calculated erosion.

A commonly used equation for reconstructing past ice sheet profiles (Paterson, 1981) relates ice mass half width (L), distance from the center (x), and ice thickness (h) as follows:

$$
h=3.4 \sqrt{(L-x)}
$$

This equation rests on a number of simplifying assumptions, some of which include a horizontal rigid bed, uniform bed roughness and temperature, a steady-state mass balance, and that the glacier is frozen to the bed. In particular the latter assumption causes a relatively steep profile. Melting conditions at the base would lower the surface significantly. Boulton and Jones (1979) showed evidence of deformable bed conditions in Iceland that would lower the surface profile of glaciers and presented theoretical profiles for various types of deformable till beds.

In the following, both Paterson's (1981) and Boulton and Jones' (1979) theoretical profiles are used in discussing past ice sheet thicknesses across the Prydz Bay shelf using sea level or, more correctly, the buoyancy line as reference level for the theoretical profiles. The paleodepth of the water, for which there are poor constraints, is for this purpose considered insignificant, and only effective ice thicknesses are discussed.

The uppermost load event, 4, may be caused by glacier loading only. This assumption is supported by the relatively low $\mathrm{Pc}^{\prime}$ values and the rate at which the overconsolidation seems to decrease downcore (near-normal consolidation just above the next downcore load event, 3, at Site 742). At Site 739, $30 \mathrm{~km}$ from the shelf edge, a pure ice load implies an effective ice thickness of $220 \mathrm{~m}$. Equation (1) gives a thickness of approximately $600 \mathrm{~m}$ at a distance of $30 \mathrm{~km}$ from the front. However, using Boulton and Jones' (1979) curves, $220 \mathrm{~m}$ thickness would fit a profile calculated for a till bed with a cohesion of 0.8 bar. Extrapolation then gives a thickness of $350 \mathrm{~m}$ at Site 742 , whereas extrapolating the profile of equation (1) would give approximately 800 $\mathrm{m}$ of effective ice thickness at this site. These two theoretical ice profiles are used to calculate the amounts of erosion necessary to obtain the observed consolidation at the various load events (Table 4).

Despite a wide estimated range (Table 4), erosion seems to have been significant and played an important role in the consolidation history of the glacigenic shelf sediments. At Site 739, which has the best geotechnical coverage, a total accumulated erosion ranging between 650 and $1500 \mathrm{~m}$ for the entire glacial period is estimated from the two models. Based on the lithostratigraphy of Sites 739 and 742 , we consider the deformable till bed scenario (Boulton and Jones, 1979) most likely in Prydz Bay, and hence, an ice surface profile less steep than calculated from Paterson's (1981) equation is the most probable. Glacier surface elevations in the order of $200-250 \mathrm{~m} 30 \mathrm{~km}$ from the terminus are also compatible with reconstructions of the Scandinavian ice sheet's extension into the North Sea during the late 
Table 4. Calculated amounts of ice and/or sediment necessary to explain the preconsolidation stresses.

\begin{tabular}{|c|c|c|c|c|c|c|c|c|c|}
\hline \multirow[b]{2}{*}{ Site } & \multirow[b]{2}{*}{$\begin{array}{l}\text { Load } \\
\text { event }\end{array}$} & \multirow[b]{2}{*}{$\begin{array}{l}\text { Depth } \\
\text { (mbsf) }\end{array}$} & \multirow[b]{2}{*}{$\begin{array}{l}\text { Excess Pc' } \\
(\mathrm{kPa})\end{array}$} & \multirow{2}{*}{$\begin{array}{l}\text { Ice } \\
\text { only } \\
\text { (m) }\end{array}$} & \multirow{2}{*}{$\begin{array}{l}\text { Sediments } \\
\text { only } \\
\text { (m) }\end{array}$} & \multicolumn{2}{|c|}{$\begin{array}{c}\text { Paterson } \\
\text { (1981) }\end{array}$} & \multicolumn{2}{|c|}{$\begin{array}{l}\text { Boulton and } \\
\text { Jones (1979) }\end{array}$} \\
\hline & & & & & & $\begin{array}{l}\text { Ice } \\
\text { (m) }\end{array}$ & $\begin{array}{c}\text { Erosion } \\
(\mathrm{m})\end{array}$ & $\begin{array}{l}\text { Ice } \\
\text { (m) }\end{array}$ & $\begin{array}{c}\text { Erosion } \\
\text { (m) }\end{array}$ \\
\hline 739 & 4 & 24 & 1900 & 220 & 160 & 600 & 0 & 220 & 0 \\
\hline 739 & 3 & 113 & 6100 & 690 & 520 & 600 & 70 & 220 & 350 \\
\hline 739 & 2 & 146 & 7900 & 900 & 670 & 600 & 220 & 220 & 510 \\
\hline 739 & 1 & 192 & 9500 & 1080 & 810 & 600 & 360 & 220 & 640 \\
\hline 742 & 4 & \multicolumn{3}{|c|}{ No tests, assumed event } & & 800 & 0 & 350 & 0 \\
\hline 742 & 3 & 134 & 5900 & 650 & 480 & 800 & 0 & 350 & 220 \\
\hline 742 & 2 & \multicolumn{2}{|c|}{ Not recorded } & & & 800 & 0 & 350 & \\
\hline 742 & 1 & 195 & 8900 & 1000 & 760 & 800 & 150 & 350 & 490 \\
\hline
\end{tabular}

Note: Three different scenarios are used: (1) pure ice or sediment loads, respectively, (2) ice thickness according to the theoretical ice surface profile of Paterson (1981), and (3) ice thickness according to Boulton and Jones (1979) for a deformable till bed of cohesion 0.8 bar. Excess $\mathrm{Pc}^{\prime}$ is preconsolidation stress corrected for the weight of the sediment between the position of the load event and the first consolidation test below the event. The ice thicknesses include only the effective thickness (i.e., above the buoyancy level). Bulk densities used are 0.9 and $2.25 \mathrm{~g} / \mathrm{cm}^{3}$ for ice and sediment, respectively.

Weichselian (late Wisconsin) maximum (Nesje et al., 1988). Erosion approaching the values used in the column of Table 4 labelled Boulton and Jones (1979), and hence a total erosion exceeding $1000 \mathrm{~m}$, is therefore possible. Glacial erosion of similar magnitude has recently been indicated for the Quaternary from the Barents Sea (Eidvin and Riis, 1989).

Only tentative estimates of the possible effects of creep can be given, based on short-term measurements, mostly on other sediment types. According to Lambe and Whitman (1979), a deformation of $0.5 \%$ per logarithmic decade may be expected for normally consolidated clays of low plasticity. Values measured on tills in Denmark, on the other hand, vary from $0.05 \%$ to $0.1 \%$ per time decade (B. Larsen, pers. comm., 1990). Considering the low plasticity and coarse grained nature of the Prydz Bay diamictites (Solheim et al., this volume), the lower set of values seems the most likely. Also, as creep rate is reported to decrease with time, we assume that the most significant part of the secondary deformation takes part during the first 1000 years. After the sediment achieved its overconsolidation creep has been insignificant. Hence, a total creep in the order of $0.5 \%$ is considered possible.

The effect of creep reduces the amount of erosion necessary to explain the unloading which results in the steps in $\mathrm{Pc}^{\prime}$. Using the glacier surface profile after Paterson (1981) (Table 4), ice load and creep can explain load events 3 and 4, whereas erosion still is important in events 1 and 2 . For the thinner, and probably more realistic, profile by Boulton and Jones (1979) (Table 4), removal of the creep effect will still leave erosion of 200-500 m for events 1,2 , and 3 , and a total cumulative erosion of up to $1100 \mathrm{~m}$ is possible, even correcting for creep as high as $1.0 \%$.

The apparent increase in amounts of erosion with increasing time (Table 4) is probably real and is also reflected in the duration of hiatuses in the cored sequence (Barron, Larsen, et al., 1989). Differences between sites for the individual events may reflect differential erosion, but may also mostly be caused by uncertainties linked to the many assumptions and simplifications made. Among the most important unknowns and sources of errors are:

1. Glacier thermal regime, although nonfrozen conditions are assumed here.

2. Possible erosion at event 4 , where only ice load is assumed.

3. Poor age control.

4. Undetected consolidation events because of undersampling.
5. Analytical errors.

6. Uncertainties in estimating the bulk densities of eroded sediments.

7. How the theoretical glacier profiles will be influenced by marine conditions, relative sea level, and changes in regional bed slope, related to isostatic variations.

8. Creep (discussed in preceding sections).

\section{Chronology of the Load Events}

Establishment of a firm chronology for the load events, as well as correlation with other Antarctic or global data, is strongly hampered by the poor age constraints. However, some inferences may be made.

The deepest load event (1), appears to be recorded stratigraphically below the seismically defined angular unconformity (Figs. 2 and 7) interpreted to represent the early Oligocene-late Miocene hiatus at Sites 739 and $\mathbf{7 4 2}$. This would imply that the loading took place before the unconformity was formed, that is, during the time represented by the upper part of the prograding sequence (Fig. 2). However, because the shelf break probably was near Site 739 at the time of deposition of this part of the prograding sequence (Barron, Larsen, et al., 1989), extensive ice thickness or major glacial erosion is unlikely. A relation between the erosion causing the major Oligocene-Miocene hiatus and load event 1 is considered more likely.

The discrepancy between the unconformity and the load event may only be apparent if the upper part of lithostratigraphic Subunit IIIA of Site 739 (Fig. 7), above load event 1, is formed subglacially, during a post-hiatus glacial advance reworking the underlying upper Eocene-lower Oligocene strata. Poorer preservation of diatoms in Core 119-739C-25R and the upper part of Core 119-739C-26R relative to those below (J. Barron, pers. comm., 1989) gives further support to such a hypothesis, and slickensides found in Core 119-739C-26R also favor a subglacial origin (Barron, Larsen, et al., 1989). We therefore propose that the true position of the hiatus is in the lowest part of lithostratigraphic Subunit IIIA, possibly at the boundary between Subunits IIIA and IIIB, and that Cores 119-739C-25R and 119$739 \mathrm{C}-26 \mathrm{R}$ contain subglacial sediments with reworked diatoms from the underlying strata. The apparent position of the unconformity, as expressed in the seismic records, the physical properties, and the logging results, is mainly dependent on the grainsize distribution of the diamictites (Solheim et al., this volume). The top of Subunit IIIA marks a transition into a more finegrained sediment and therefore shows a change in physical prop- 
erties, as exemplified by the water content (Fig. 7). A subglacial reworking and deposition as basal till also explain why sediments both below and above the load event show similar characteristics despite a different degree of compaction, as little sorting would be expected in this environment. Studies from other regions show that basal tills in general are of relatively local origin (10-50 km) (Gross and Moran, 1971; Lundqvist, 1977; Haldorsen, 1977; Vorren, 1979). In fact, reworking of diatombearing glacial marine sediments similar to that found in Subunit IIIB is a possible source for the material of Subunit IIIA.

Significant errors in estimation of $\mathrm{Pc}^{\prime}$ are considered unlikely for the two tests determining the lower load event, 1, at Site 739 (Figs. 5 and 6). The fact that the same discrepancy between the lowermost recorded load event and the unconformity is found at Site 742 gives further support to the preceding discussion. At this site, Core 119-742A-20R (171.3-181.0 mbsf) has rare fragments of Oligocene to Eocene diatoms (Barron, Larsen, et al., 1989). However, barren intervals on the order of 30-50 $\mathrm{m}$ above and below this core make exact localization of the hiatus uncertain. Although the quality of the consolidation tests defining load event 1 at Site 742 is poorer than at Site 739 , the same arguments concerning its position relative to the hiatus/unconformity can also be used at Site 742 .

In conclusion we interpret load event 1 , identified at Sites 739 and 742 , to be related to a long period of erosion by glaciers reaching the shelf edge. The onset of this glacial expansion took place in the early Oligocene and marked the end of a period of shelf progradation through glacigenic deposition. Early Oligocene expansion of grounded ice in Prydz Bay corresponds well with increased ice rafting in other parts of the Southern Ocean (Leg 113 Shipboard Scientific Party, 1987; Leg 119 Shipboard Scientific Party, 1988), as well as with results of the recent
CIROS-1 drilling in the Ross Sea (Barrett, 1989). Furthermore, Birkenmajer (1986) reported Eocene diamictites from the South Shetland Islands. Based on global oxygen isotope data on planktonic foraminifers, Prentice and Matthews (1988) also proposed significant volumes of Antarctic glacier ice for the last 40 m.y. A similar conclusion was drawn by Miller et al. (1987), based on benthic species. Through glaciological and climatical considerations, Robin (1988) also proposed extensive Antarctic glaciations from around $40 \mathrm{Ma}$, with great fluctuations during the first 20 m.y. A number of major glacial advances and retreats may explain the extensive erosion estimated.

Figure 8 shows a tentative diagram of the glacial history based on the recorded load events. The eustatic sea-level curve compiled by Haq et al. (1987) is also shown, but the poor time constraints for the cored sediments limit the possible comparison between the two.

Load event 2 is recorded in a late Miocene interval at Site 739. This may be correlated with a distinct eustatic sea-level drop at approximately $10 \mathrm{Ma}$ (Fig. 8). A major build-up of ice in West Antarctica is suggested at this time (Leg 113 Shipboard Scientific Party, 1987; Barker et al., 1988). Composite oxygen isotope data compiled by Miller et al. (1987) also indicate an ice growth event at $10 \mathrm{Ma}$. That this climatically significant event also affected East Antarctica is likely. Sites drilled on the Kerguelen Plateau during ODP Leg 119 show increased ice rafting and biosiliceous sedimentation from the late Miocene (Barron, Larsen, et al., 1989), and Ehrmann et al. (this volume) record late Miocene ice rafting events around $8 \mathrm{Ma}, 6.2 \mathrm{Ma}$, and 4.7 Ma on the Kerguelen Plateau.

Event 3 marks a distinct increase in Pc' at both Sites 739 and 742 , but because of greater sample density, its position is more clearly defined at Site 739 than at Site $\mathbf{7 4 2}$. The biostratigraphy

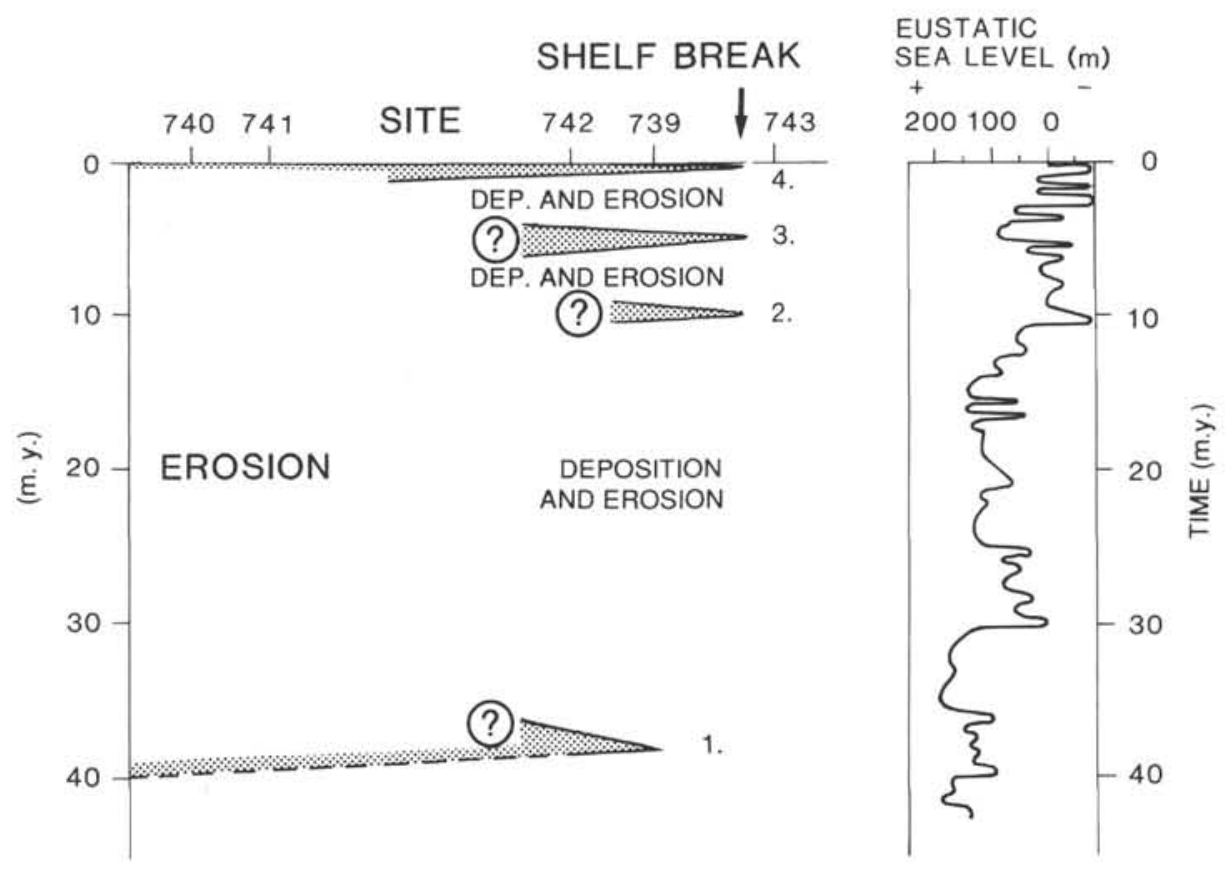

Haq et al. (1987)

Figure 8. Simplified glacial history diagram for the Prydz Bay continental shelf, based on the consolidation test results. Numbers 1 through 4 mark the interpreted load events. A glacial advance is indicated at each load event, but this probably marks only the beginning of a series of glaciations that cause the inferred erosion. The erosion above each indicated event is the main factor causing the stepwise rise of $\mathrm{Pc}^{\prime}$. The eustatic sea level curve of Haq et al. (1987) is shown, and relations between the consolidation history and the sea level discussed in the text. 
indicates an early Pliocene age at Site 739 and late early to early late Pliocene at Site 742. The Pliocene part of the global eustatic sea-level curve (Fig. 8) has great and frequent fluctuations, and a direct correlation to this curve is impossible without more precise dating. Data from the Weddell Sea indicate intensified glaciation during the late Pliocene, related to the onset of glaciations in the Northern Hemisphere (Leg 113 Shipboard Scientific Party, 1987; Barker et al., 1988), and Ehrmann et al. (this volume) show an ice rafting event at approximately $3.6 \mathrm{Ma}$ on the Kerguelen Plateau. Due to poor core recovery in the upper approximately $100 \mathrm{~m}$ at Site 739 , there is little control on both lithofacies and biostratigraphy in this part of the drilled sequence. At Site 742, long-ranging diatom assemblages (Oligocene-Quaternary) do not give any constraints (Barron, Larsen, et al., 1989). Load event 3 appears, however, as a distinct geotechnical boundary, and we ascribe it to significant, regional glacial erosion occurring during a period within early Pliocene to Quaternary time. From the discussion on the consolidation between events 3 and 4, later glaciations and periods/amounts of glacial erosion have not been as extensive as for events 1 through 3.

The upper load event, 4, marks the transition from overconsolidated to normally consolidated sediments (from diamictites to diamictons). The fossil assemblages for these upper intervals at both Sites 739 and 742 give Pliocene to Quaternary ages. However, based on the geotechnical data, the diamictons are most likely deposited after the last period that grounded ice reached the shelf edge, which for other parts of the Antarctic continental shelf is interpreted to have occurred during the late Weichselian maximum (Elverhøi and Maisey, 1983). The exact position of the boundary is, however, difficult to place due to very poor core recovery in the upper part of both Sites 739 and 742 (Fig. 5).

\section{SUMMARY AND CONCLUSIONS}

A total of 18 consolidation tests were carried out on wholeround core samples of the sedimentary sequence in Prydz Bay. Three tests were performed in presumably preglacial terrestrial sediments, two in diamictons of presumably Quaternary age, and the remaining thirteen tests were performed on glacial diamictites ranging back to early Oligocene time. The samples were loaded up to an effective axial stress of $24,000 \mathrm{kPa}$, and preconsolidation stresses $\left(\mathrm{Pc}^{\prime}\right)$ of up to $10,000 \mathrm{kPa}$ were estimated in the diamictites. Despite difficulties in the interpretation of some of the consolidation curves, the results were used to estimate minimum past loads, as ice and/or eroded sediment thicknesses. Distinct steps in the general downcore increase in $\mathrm{Pc}^{\prime}$, here termed load events, are interpreted as periods of extensive glaciations loading and eroding the shelf sediments. These load events are correlated between sites and provide information about the large-scale glacial history of the region.

The following main conclusions can be drawn from this study:

1. Four separate load events, 1 through 4 , each representing extensive periods of glaciation and glacial erosion across the continental shelf, were identified in the glacigenic sediments of Site 739.

2. At Sites 740 and 741 , extensive erosion removed most of the glacial sediments and caused high overcompaction of the underlying continental sediments. Only the uppermost load event, 4, can tentatively be identified based on lithostratigraphy and shipboard physical-properties data.

3. Glacial erosion played a significant role in the consolidation history of the shelf sediments. Using theoretical glacier surface profiles for an ice sheet extending to the shelf edge, the total, cumulative erosion since early Oligocene at Site 739 possibly exceeds $1000 \mathrm{~m}$. Individual load events may represent several hundred meters of erosion.
4. A tentative chronology for the load events relates event 1 to the major hiatus ranging at least from early Oligocene to late Miocene, representing an extensive, early phase of major glacial oscillations across the shelf. Event 2 is suggested to correlate with advances related to the build-up of ice in West Antarctica. Load event 3 is ascribed to extensive glacial erosion that probably occurred during the early Pliocene, whereas the upper event, 4 , marks the last period of grounded glacier ice extending to the shelf edge, possibly as late as the late Weichselian (late Wisconsin).

5. Consolidation tests may be important for determining the true position of erosional unconformities formed in a subglacial environment.

\section{ACKNOWLEDGMENTS}

The present study was funded by the Royal Norwegian Council for Science and the Humanities (NAVF), under grants no. D.48.40.072 and 443.89/023. The Norwegian Geotechnical Institute provided laboratory facilities and technical expertise at favorable prices. Astrid Stadheim is acknowledged for carrying out all preparation work for the consolidation tests. Mona Nyland Berg, Sten Boye Flood, and Bengt Bjarne Larssen also took part in the analyses work. Susan Barr and Toralv Berre gave critical comments on the manuscript. This is the Norwegian Polar Research Institute contribution no. 270.

\section{REFERENCES}

Andresen, A., Berre, T., Kleven, A., and Lunne, T., 1979. Procedures used to obtain soil parameters for foundation engineering in the North Sea. Norw. Geotech. Inst. Publ., 129:1-18.

Atkinson, J. H., and Bransby, P. L., 1978. The Mechanics of Soils: An Introduction to Critical State Soil Mechanics: London (McGrawHill).

Barker, P. F., Kennett, J. P., and Leg 113 Shipboard Scientific Party, 1988. Weddell Sea palaeoceanography: preliminary results of ODP Leg 113. Palaeogeogr., Palaeoclimatol., Palaeoecol., 67:75-102.

Barrett, P. J. (Ed.), 1986. Antarctic Cenozoic history from the MSSTS-1 drillhole, McMurdo Sound. DSIR Bull., 237.

, 1989. Antarctic Cenozoic history from the CIROS-1 drillhole, McMurdo Sound. DSIR Bull., 245.

Barrett, P. J., and Treves, S. B., 1981. Sedimentology and petrology of core from DVDP-15, western McMurdo Sound. In McGinnis, L. D. (Ed.), Dry Valley Drilling Project: Am. Geophys. Union Antarct. Res. Ser., 33:281-314.

Barron, J., Larsen, B., et al., 1989. Proc. ODP, Init. Repts., 119: College Station, TX (Ocean Drilling Program).

Birkenmajer, K., 1986. Geochronology of Tertiary island-arc volcanics and glacigenic deposits, King George Island, South Shetland Islands (West Antarctica). Bull. Pol. Acad. Sci. Earth Sci., 34:257-273.

Boulton, G. S., and Jones, A. S., 1979. Stability of temperate ice caps and ice sheets resting on beds of deformable sediment. J. Glaciol., $24: 29-42$.

Boulton, G. S., and Paul, M. A., 1976. The influence of genetic properties on some geotechnical properties of glacial tills. Q. J. Eng. Geol., 9:159-194.

Brooker, E. W., and Ireland, H. O., 1965. Earth pressures at rest related to stress history. Can. Geotech. J., 2:1-15.

Casagrande, A., 1936. The determination of the preconsolidation load and its practical significance. Proc. First Inter. Conf. Soil Mech. and Found. Eng., 3:60-64.

Chamberlain, E. J., 1979. Overconsolidated sediments in the Beaufort Sea. North. Eng., 10:24-29.

1989. Physical changes in clays due to frost action and their effect on engineering structures. In Rathmayer, H. (Ed.), Frost in Geotechnical Engineering. Int. Symp. Saariselka, Finland (Tech. Res. Center of Finland).

Chamberlain, E. J. and Gow, A. J., 1978. Effect of freezing and thawing on the permeability and structure of soils. Int. Symp. on Ground Freezing, Ruhr University, Bochum, Germany, 31-44.

Drewry, D. J. (Ed.), 1983. Antarctica: Glaciological and Geophysical Folio: Cambridge (Scott Polar Research Institute).

Drewry, D. J., and Robin, G. de Q., 1983. Form and flow of the Antarctic ice sheet during the last million years. In Robin, G. de Q. (Ed.), 
The Climatic Record in Polar Ice Sheets: Cambridge (Cambridge Univ. Press), 28-38.

Eidvin, T., and Riis, F., 1989. Nye dateringer av de tre vestligste borehullene i Barentshavet. Resultater og konsekvenser for den tertiære hevningen. Nor. Petrol. Direct., 27.

Elverhøi, A., and Maisey, G., 1983. Glacial erosion and morphology of the eastern and southeastern Weddell Sea shelf. In Oliver, R. L. James, P. R., and Jago, J. B. (Eds.), Antarctic Earth Science: Proc. 4th Inter. Symp. Antarctic Earth Sci., Adelaide, Australia, 1982, 483-487.

Gross, D. L., and Moran, S. R., 1971. Grain size and mineralogical gradations within tills of the Allegheny Plateau. In Goldthwait, R. P. (Ed.), Till: A Symposium: Columbus (Ohio State Univ. Press), 251274.

Haldorsen, S., 1977. Morener, dannelser, klassifikasjoner og egenskaper. Nor. Landbrukshgskole, Inst. Geologi, Rapport, 5.

Hambrey, M. J., Larsen, B., Ehrmann, W. U., and ODP Leg 119 Shipboard Scientific Party, 1989. Forty million years of Antarctic glacial history yielded by Leg 119 of the Ocean Drilling Program. Polar Rec., 25:99-106.

Haq, B. U., Hardenbol, J., and Vail, P. R., 1987. Chronology of fluctuating sea levels since the Triassic. Science, 235:1156-1167.

Hayes, D. E., Frakes, L. A., et al., 1975. Init. Repts. DSDP, 28: Washington (U.S. Govt. Printing Office).

Janbu, N., 1970. Grunnlag $i$ Geoteknikk: Trondheim, Norway (Tapir Forlag).

Lacasse, S., 1988. Design parameters of clays from in situ and laboratory tests. Nor. Geotech. Inst., Int. Report, 52155-50:1-20.

Lambe, T. W., and Whitman, R. V., 1979. Soil Mechanics, SI Version: New York (Wiley).

Leg 113 Shipboard Scientific Party, 1987. Glacial history of Antarctica. Nature, 328:115-116.

Leg 119 Shipboard Scientific Party, 1988. Early glaciation of Antarctica. Nature, 333:303-304.

Lundqvist, J., 1977. Till in Sweden. Boreas, 6:73-85.
Miller, K. G., Fairbanks, R. G., and Mountain, G. S., 1987. Tertiary oxygen isotope synthesis, sea level history, and continental margin erosion. Paleoceanography, 2:1-19.

Nesje, A., Dahl, S. O., Anda, E., and Rye, N., 1988. Block fields in southern Norway: significance for the late Weichselian ice sheet. Nor. Geol. Tidsskr., 68:149-169.

Paterson, W.S.B., 1981. The Physics of Glaciers (2nd ed.): Oxford (Pergamon Press).

Prentice, M. L., and Matthews, R. K., 1988. Cenozoic ice-volume history: development of a composite oxygen isotope record. Geology, 16:963-966

Robin, G. de Q., 1988. The Antarctic ice sheet, its history and response to sea level and climatic changes over the past 100 million years. $\mathrm{Pa}$ laeogeogr., Palaeoclimatol., Palaeoecol., 67:31-50.

Sandbakken, G., Berre, T., and Lacasse, S., 1986. Oedometer testing at the Norwegian Geotechnical Institute. In Yong, R. N., and Townsend, F. C. (Eds.), Consolidation of Soils: Testing and Evaluation: Philadelphia (ASTM) STP 892, 329-353.

Schmertmann, J. H., 1955. The undisturbed consolidation behavior of clay. Trans. Am. Soc. Civ. Eng., 120:1201-1227.

Stagg, H.M.J., 1985. The structure and origin of Prydz Bay and MacRobertson Shelf, East Antarctica. Tectonophysics, 114:315-340.

Taylor, D. W., 1942. Research on consolidation of clays. MIT Series, 82.

Terzaghi, K., 1943. Theoretical Soil Mechanics: New York (Wiley).

Vialov, S. S., 1958. Regularities of glacial shields movement and the theory of plastic viscous flow. Int. Assoc. Sci. Hydrol., 47:266-275.

Vorren, T. O., 1979. Weichselian ice movements, sediments and stratigraphy on Hardangervidda, South Norway. Nor. Geol. Undersokelser, 350:1-117.

Date of initial receipt: 4 October 1989

Date of acceptance: 24 July 1990

Ms 119B-18? 